\title{
Green Marketing Practices for Sustainable Business Growth in Bangladesh: A Case Study of Dhaka City
}

\author{
Md. Ruhul Amin ${ }^{1}$, Ishtiaque Arif ${ }^{2}, \&$ Mohammad Maksudur Rahman ${ }^{3}$
}

${ }^{1}$ Lecturer, Department of Public Administration, Comilla University. Comilla, Bangladesh.

${ }^{2}$ Assistant Professor, Business Administration, Southeast University, Dhaka. Bangladesh

${ }^{3}$ Deputy Registrar, Southeast University, Dhaka. Bangladesh.

\begin{abstract}
Green marketing is a way to use the environmental benefits of a product or service to promote sales. Many consumers will choose products that do not damage the environment over less environmentally friendly products, even if they cost more. With green marketing, advertisers focus on environmental benefits to sell products such as biodegradable diapers, energy-efficient light bulbs, and environmentally safe detergents. As a Bangladeshi citizens are very much unaware about green marketing which portrait their unconsciousness of environment. Here authors have tried to sketch the problems and prospects of green marketing along with to draw attention of readers' to make them consciousness about the pollution of environment.
\end{abstract}

Keywords: Green Marketing, Environment, Pollution, Dhaka, Bangladesh.

\section{JEL Classification Code: M30; M31; M39}

\section{INTRODUCTION}

Green marketing concept incorporates a broad range of activities for establishing the consumer rights, protecting the environment and meeting the consumer needs. In the present world consumers are more conscious about their safety of life and want everything would be environment friendly and making the green world. Green marketing battles with deceptive practices, grey marketing, food adulteration and protects consumers from unscrupulous businessman. This concept is already activated all over the world. So Bangladesh would not be out of this. By now, from the Government to different parties, agencies, NGO's and private organizations, all are committed to shoulder the responsibilities. Unfortunately, a majority of people believe that green marketing refers solely to the promotion or advertising of products with environmental characteristics. Terms like Phosphate Free, Recyclable, Refillable, Ozone Friendly, and Environment Friendly are some of the things consumers most often associate with green marketing. While these terms are green marketing claims, in general green marketing is a much broader concept, one that can be applied to consumer goods, industrial goods and even services (May 1991, Ingram and Durst 1989, Troumbis 1991). Since 1970, green marketing concept has been included 
with different marketing philosophies, and also arising from one of the concept of Philip Kotler's five marketing management concepts (Societal marketing concept). But this concept has not been practiced properly until 1980's, because, marketers could not match it with the traditional marketing concepts, and even defining green marketing concept was not a simple task. The terminology used in this area has varied, it includes: green marketing, environmental marketing and ecological marketing.

The people of Bangladesh have been living with natural hazards and catastrophe and the infrastructure of Bangladesh is not developed. This country is polluted by many ways like air, water, noise etc. Green Marketing concept will help to protect our country. Our industry will go for customer driven policy and to create demand for green products. Bangladeshi consumers must adopt environmentally sound behaviors to sustain the clean environment. Through such conscious choices (green product), consumers can take steps to protect the earth's natural resources and to prevent further environmental damage of Bangladesh.

\section{OBJective}

The purpose of this paper is to explore the problems and prospects of Green Marketing in Bangladesh. The main reasons for applying the green marketing concept in Bangladesh are that-

- $\quad$ To introduces the term of green marketing.

- To justify Bangladesh's perspective on the platform of Green Marketing.

- To identify some hindrances of green marketing in Dhaka City.

- To analyze the Findings of Different Organizational Activities.

\section{Methodology and Scope of the Study}

It is the nature of the research problem that should dictate the appropriate research method: sometimes quantification is required, sometimes not. Similarly, Punch (1998) observes that "quantitative questions require quantitative methods to answer them and qualitative questions require qualitative methods to answer them". The major objective of this study is to highlight the areas which have been organized and desired to be organized for making the pollution free environment. Secondary and primary data were helpful for collecting the required information. The secondary sources of data are journals, books, magazines and different organization's past, present activities and the future planning is also included with them. These types of information will help for descriptive research studies. Descriptive research helped for identifying and describing the characteristics in different situation. The secondary data helped for describing the overall situation in Bangladesh for making the green Bangladesh. The primary data are collected by making the focus group interview with the general public and people in civil societies. By the focus group interview, the respondent's feelings, attitudes, ideas and beliefs have been easily collected. The bright ideas for future planning to protect our country also gathered through the interviews.

\section{Concept of Green Marketing}

A variety of terms are used to capture the essence of green marketing and these range from environmental marketing, eco-friendly marketing, sustainable marketing, ecologicallycorrect marketing to ecological marketing. Polonsky (1994) defines green marketing as "all activities designed to generate and facilitate any exchanges intended to satisfy human needs or wants, such that the satisfaction of these needs and wants occurs, with minimal detrimental impact on the natural environment". In the words of Peattie (1995), green 
marketing is "the holistic management process responsible for identifying and satisfying the requirements of customers and society, in a profitable and sustainable way".

The term "green marketing" describes an organization's efforts at designing, promoting, pricing and distributing products that will not harm the environment (Pride and Ferrell, 1993). Green marketing started to play dominance role for consumer's satisfaction when public expressed their demand for green products or services and green life. And then green concept came into prominence in the late 1980's and early 1990's. The word "environmentally preferable" considers - the products and services which would be matched with the environment friendly and from the manufacturing to the packing and selling of the products must have to be protected from deception and unprincipled things. One Study focused on promoting "sustainable marketing", a strategy that deals positively with ecological environment and is sensitive to the needs of future generations in areas including product, price, distribution channel, and promotion (Murphy, 2005). These efforts have been encapsulated by green marketing philosophy, which reflects concern about the effects of manufacturing and consumption on the environment.

Organizations engaged in the marketing of eco-friendly products and ideas include both business and non-business organizations. While business firms make use of green marketing to market green products and services and/or building a green corporate image, nonbusiness firms pursue it as a non-profit activity with a view to identify, develop and promote eco-friendly ideas, products and manufacturing processes/technologies among the consumers, business firms and other organizations.

\section{Bangladesh's Perspective - Green Marketing Concept}

By location Bangladesh falls in the coastal region. She is going to be worst sufferers due to the impact of fast climate change throughout the globe. The coastal areas of Bangladesh are different from rest of the country because of their unique geo-physical characteristics and different socio-political consequences that often limit people's access to endowed resources and perpetuate risk and vulnerabilities. Bangladesh's coast is the biggest victim to natural disasters and highly affected by climate change with problems including salinity and water logging, soil erosion, flooding and cyclones. The hazards of natural disasters cannot completely be prevented, but the risks and vulnerability can be reduced through increasing capacity. It has been emphasized by the experts that capacity building also depends on the economical condition as well as political commitment of a country, which is why the Concept Green Marketing has become a dire need for this country. The other deep rooted problems like unplanned urbanization, industrialization, motorization etc have been added to the devastating effect of effect of climate change and echo diversity.

\section{HindRances of Green Marketing}

7.1. Unplanned Urbanization: Unplanned urbanization has become a powerful threat to environment. Especially, Real estate sectors indicate another factor to deteriorating environment. Presently, this sector maintains a booming position in our country. It's a very profitable business and at the same time, consumer's purchasing power helps maintaining a healthy economy. But, some important stakeholder's mal practices like filling up natural water logged areas, cutting trees, irregular earth-filling, not leaving enough free spaces to grow greens and human etc. resulting catastrophic natural disasters. These are the causes for accidental death too. The Green of Dhaka city is disappearing fast due to the fast growing of unmanaged number of real estate 
projects. Negligence to the restrictions of Municipality rules, DAP, RAJUK and disrespect to the Democratic power has left the mal-practioner in safe heaven.

7.2. Lack of Good Governance: Wikipedia terms "Governance" as "the process of decisionmaking and the process by which decisions are implemented (or not implemented)". "The term governance can apply to corporate, international, national, local governance or to the interactions between other sectors of society." Good Governance can help us position our green products and services to maximize public perception and generate positive top-ofmind publicity. From innovative green marketing strategies to public relations, and sustainable eco-friendly business policies, The Good Governance can be our link to a stronger market perception as a truly Generous Host. For which the practice of good Management is a must. The abilities of the local management to delineate and delegate responsibilities to various organizations and ensuring accurate responding and monitoring of delegating responsibilities can be termed as the decentralized management. Decentralized and well coordinated powerful management is the tool to stop any irregularities. The co-existence of various local government bodies, such as city corporation, pourashava union council, local and development authority (like- RAJUK) and other organizations WASA, DESA, etc. should have been more dedicated to perform their jobs. If, the various organs of local government would have been exercising their authority to follow the rules and regulations, then environment would have been saved from the hands of encroachers. To work in line with environment friendly concepts every developer should take approval of different agencies for a specific project before construction. Approvals are required from the following Governmental departments:

- Civil Aviation

- Ward Commissioners of the specific project site

- Dhaka Water and Sewerage Authority (DWASA)

- DESA / DESCO

- Dhaka Transport Coordination Broad (DTCB)

- Department of Environment (DOE)

- Rajdhani Unnayan Kartipakhya (RAJUK)

Good urban governance can be achieved if harmonization of various organs is ensured. Good urban governance can be a useful mechanism to enhance the legitimacy of the public realm. The requirements for good urban governance are nearly endless, but above all it should basically aim at creating environment friendly planned urban areas.

7.3. Unplanned Industrialization and Motorization: Traffic jam is a common scenario in our country now a day. The excessive use of motor cars has increased the lead level in air of atmosphere at a dangerous state. Not only the travelers but also the dwellers life is at a stake. The industrialization in urban residential areas has made it more difficult. The burnt smoke and poisonous liquids have endangered the lives of all groups in the cities. The use of chemicals in the residential hubs and flow of poisonous liquids through the rivers and canals have not only endangered the lives but also ignored the breath of the environment.

\section{Findings and Analysis of Different Organizational Activities}

From Government to private organizations, everybody's are becoming more conscious for protecting Bangladesh from detrimental impact on the natural environment.

\subsection{Government}

Government is the key role player to react and ensure its defense. It should implement all its rules regarding safety of the nation. First of all, the laws which had been provided by the 
Government must be maintained strictly by the businessman. Thus governmental attempts to protect consumers from false or misleading claims should theoretically provide consumers with the ability to make more informed decisions. For example, some governments have introduced voluntary curb-side recycling programs, making it easier for consumers to act responsibly. The Government actions can easily protect the consumers and society by implications of green marketing concept. So Government can take different steps like:

1) Impose restriction on the production of harmful goods or by-product items which would be harmful for consumers and society.

2) Ensuring consumer friendly society to practice the ability to evaluate the environmental composition of goods.

3) Ensuring commerce rules in favour of consumer's rights and choices over the products.

4) Ensuring hurdles for wrong practices in the sector of production un-friendly to the environment.

\subsection{Bangladesh Poribesh Andolon (BAPA)}

Bangladesh Poribesh Andolon (BAPA) was launched in 2000 to create a nation wide, united, and strong civic movement to protect Bangladesh's environment. The environment of Bangladesh is deteriorating fast. Urban air quality is plummeting. Ground water is contaminated. Surface water bodies are getting polluted, encroached, and degraded. Solid, fluid, gaseous, and hazardous wastes are overflowing. Forests and open spaces are disappearing. Noise is increasing. Bio-diversity is vanishing. Health conditions are worsening due to pollution. Unless these processes of degradation are slowed down and reversed, the country's economic, social, cultural, and human progress will be gradually hampered, and Bangladesh will become unlivable in the long-term. In this backdrop, proenvironment forces of Bangladesh gathered at the International Conference on Bangladesh Environment (ICBEN) in January 2000 to discuss Bangladesh's environmental problems and chart out actions for the future. The conference adopted Dhaka Declaration on Bangladesh Environment 2000 and suggested formation of a unified platform for all sincere proenvironment forces of the country to join and work together.

\subsubsection{Objectives}

BAPA's concrete objectives are:

To stop the process of further environmental degradation in Bangladesh.

To reverse, where possible, the damage that has already been done to the environment.

To build up a nationwide, united, civic movement to achieve the aims of stopping and reversing environmental degradation in Bangladesh.

\subsubsection{Achievements}

BAPA has already been able to bring about certain positive changes in Bangladesh environment. Working together with other pro-environment forces, BAPA has been successful to-

- Make the government implement removal of two-stroke engine vehicles (TSEV) that were one of the major causes of urban air pollution in Bangladesh.

- Make the government to put an end to the use of leaded gasoline in Bangladesh.

- Initiate a river saving movement in Dhaka, leading to the removal of many structures encroaching rivers in and around Dhaka.

- Organize the International Conference on Regional Cooperation on Transboundary Rivers (ICRCTR) 2004 to draw attention to the likely impact of the proposed Indian River Linking Project (IRLP) and leading to the publication of the volume that is now the most comprehensive source of information and analysis regarding IRLP. 
- Adopt a comprehensive Resolution on Rivers that reveals the flaws of the Commercial Approach to rivers and argues for the Ecological Approach to rivers.

- Initiate a country-wide river saving movement through organization of the National Conference on Rivers in 2006.

- $\quad$ Organize the National Conference on Energy and Environment to discuss and adopt the comprehensive Resolution on Energy, as a guide for future sustained campaign on these issues.

\subsection{Bangladesh Environmental Lawyers Association (BELA)}

BELA was initiated in 1992 by a group of lawyers to address the need for an advocacy group to monitor and pursue the implementation of laws and regulations to protect the environment. Dr. Mohiuddin Farooque was the main initiator of BELA.Over the years, BELA has become a pressure group against environmental violations, and its research has played an important role in popularizing the environment amongst the general public. BELA in Bangladesh include: research into legal documents to minimize the gap between provisions of law and people's expectations, including laws on compensation and on regulating environment and customs on forests and intellectual property rights.

\subsubsection{Objectives \& Strategies}

The broad objective of BELA is to promote environmental justice and contribute towards the development of a sound environmental jurisprudence.

The specific objectives of the organization include:

- Undertake studies on and research into the local, national, \& international regulatory regime on environment.

- Undertake legislative advocacy.

- Seek judicial or administrative relief to ensure implementation of existing environmental laws.

- Resolve environmental disputes through count cases, alternative dispute resolution, mediation and other means.

- Develop and core group of environmental activists.

\subsubsection{Target Beneficiaries}

The beneficiary of BELA's activity is perhaps every human and non-human being. In attempting to protect people's rights and legitimate interests, BELA's efforts aimed from top echelon of the society and governance to the little mass whose lives and livelihood are often forfeited in various disguise and means.

\subsection{Consumer Association in Bangladesh (CAB)}

Consumers Association of Bangladesh (CAB) a non-government and non-profit organization, established in 1978 at the initiative of a group of Dhaka it's imbued with the idea of consumerism, a movement that already took shape in Europe and America. Since its inception, $\mathrm{CAB}$ has been trying to spread the essence of consumerism among poor and lowmiddle class consumers have attempted to organize activities for the promotion and protection of the rights and interests of the consumers. The major objectives of $\mathrm{CAB}$ are to:

- Make consumers aware of their rights and responsibilities.

- Promote consumer education, aiming at raising awareness of consumers against exploitation, and providing them with technical knowledge and support for real protection.

- Focus on consumers' problems and develop a spirit of mutual co-operation and understanding among different groups, associations, institutions, NGOs and government agencies functioning in the interests of the welfare of the people. 
- Organize and set-up consumers associations and groups at the districts and thana level.

- Undertake research studies on consumer issues and problems.

\section{CONCLUSION}

Above study and scenario depicts the progressive Bangladesh in the long cherishing hope for Green Marketing. Even the consumers also seem to be committed to make a green Bangladesh. Ultimately, green marketing concept is making all consumers aware about their rights to get fresh products; even they are ready to pay more for reducing the adulterated food. Their demand is now Government's positive intervention. Some businesses ha ve been quickly to accept concepts like environmental management systems and waste minimization, and have integrated environmental issues into all organizational activities. Progressive communities and civil societies are now taking several environmental campaigns, including 'Buriganga Bachao Andolon', 'Campaign against Air Pollution', and 'Campaign against Polythene' was conducted by BAPA. Some of them achieved notable success. BAPA also organized 'Sundarban Bachao Conference' and 'Environmental Health Conference'. In automobile segments are also aware to reduce the carbon monoxide from the environment by starting electric vehicles and Compressed Natural Gas (CNG) conversion procedure in two-wheeler, three-wheeler transportations which are environment - friendly in different organizations. The Polythene Act in 2001 has also taken an effective movement to make pollution free environment. Bangladesh Environmental Conservation Act was enacted in 1995. As per the Act"Environmental Clearance Certification" is required for the establishment of any new industries from the Director General of the Department of Environment. Inception of such policies has strengthened the movement of Green Marketing in Bangladesh.

\section{BIBLIOGRAPHY}

Ingram, C. Denise and Patrick B. Durst. 1989. "Nature-Oriented Tour Operators: Travel to Developing Countries." Journal of Travel Research 28 (2): 11-18

Kotler, P. 2003, Marketing Management, Prentice Hall of India, New Delhi.

May, V. 1991. "Tourism, Environment and Development: Values, Sustainability and Stewardship." Tourism Management 12 (2): 112-118.

Murphy, P. E. (2005). Sustainable Marketing, Business and Professional Ethics Journal, 24(1/2), pp. 199-223.

Peattie, K. 1995. Green marketing. M and E Handbooks. London: Pitman Publishing.

Polonsky, M. J. 1994. An Introduction to Green Marketing. Electronic Green Journal, 1(2). http://gopher. nidaho.edu/1/libgopher/hibrany/egj.

Pride, M.W. and Ferrell C.O. (1995), Marketing Concepts and Strategies, (9th ed.), Houghton Mifflin Company.

Punch, K.F. (1998) Introduction to Social Research: Quantitative and Qualitative Approaches. London: Sage.

Troumbis, A. Y. 1991. "Environmental Labeling on Services: The Case of Tourism." Ekistics (348/349): 167-173. 